Original Research Paper

\title{
Fostering Innovation and Methodology through Experiential Learning for Data Structures
}

\author{
K. Anitha Kumari ${ }^{1}$, L. Nanda Gopal ${ }^{2}$, R.Padmashani ${ }^{1}$ \\ ${ }^{1}$ Department of Information Technology, PSG College of Technology, Coimbatore. \\ India. \\ ${ }^{2}$ Department of Humanities, PSG College of Technology, Coimbatore. India.
}

Article History

Received:

01.12 .2020

Revised:

15.12 .2020

Accepted:

17.02 .2021

*Corresponding Author:

K. Anitha Kumari

Email:

kak.it@psgtech.ac.in

This is an open access article, licensed under: $\mathrm{CC}-\mathrm{BY}-\mathrm{SA}$

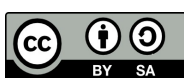

Abstract: For real-life work environment, developing employability skills by the students' community is indispensable and need of the hour. Laboratories associated with courses cultivate the ability of students to think independently and promote employability skills through experiential learning. Data structures are one such predominant course in IT/CSE domain to enhance the skill set of students for Placements/Higher studies. It provides opportunity for students to devise algorithms efficiently in an optimal manner by solving challenging problems easily thereby gaining confidence for attending placements. The purpose of this paper is to foster innovation by exploration in data structures course through experiential learning by providing coding based challenging questions as tutorials, assignment presentations and as activities during laboratory sessions and online classes are to be conducted as an essential one in the future learning perspective. Findings conclude that the experiential learning foster student's abilities in solving the problem and thereby gaining confidence during e-learning and placement activities and the grading process are to be updated through centralized servers to the maximum extend and accuracy are to be maintained.

Keyword: Challenging Problems, Data Structures, E-Learning, Experiential Learning, Grading Process. 


\section{Introduction}

Basically, student community follows the traditional way of learning and executing the programs by following a specific set of defined instructions. However, research purports that there is a profound advances in learning through experience process is required for the betterment of the learning [1]. Nowadays experiential learning is expanding its role in academic institutions to enhance the knowledge and to develop the student's skillset. It is neither a basic action, nor an ultra-sensitive reproduction. It involves solving a highly challenging problem with one's own critical thinking and problem-solving skills. This profound involvement creates better retention of new thoughts [2]. Rather than memorizing the concepts and replicating, activity based experiential learning is considered as a wise choice to learn and understand the concepts clearly. The activities are planned to involve students in higher order reasoning practices or procedures when open challenging problems are provided [3]. As a result, students pay more attention and gain more insight about the problem that is sustained for a longer period of time. Educators plays a crucial role in engaging the students in open ended challenging problems. Curriculum based activity based questions or projects are highly recommended in this paper to improve the student's performance in all aspects. The course considered for investigation of experiential learning is Data Structures, as it is undoubtedly most vital course for CSE/IT placements in the current and future scenario.

This paper is constructed in such a way to reflect the voice and thought of teachers, students and the progressed mode of investigation carried out as activities that leads to improve the involvement of students in academics in a healthier manner and practice in their regular day to day life in an efficient way. Section 2 performs a review for activity based learning methods and concerns of stakeholders involved in the experiential process, section 3 elaborates the innovative experiential learning procedures and components investigated for data structures course and its applicability section 4 explores the case study and section 5 concludes the research paper.

\section{Literature Review}

\subsection{Hypothesis}

The literature demonstrates that activity based teaching and learning, highly focused methods of instruction seem increasingly successful in improving students' performance with the support of stakeholder.

\subsection{Research Site \\ Case 1:}

A paper by Pereira J.A. et al [4] studies the impact of using multimedia technology to teach anatomy classes. A research was conducted by them with two sets of students from a class. The first group of students was exposed to only theoretical lectures, whereas the second group of students was exposed to both theory and videos related to anatomy. Findings conclude that the students who were exposed to video clips performed well in the exams rather than the other set of students.

\section{Case 2:}

According to Singha, et.al [5], a survey was conducted in the state of Assam, India for few school students, college students and teachers. The topic of discussion was teaching and learning math in schools and colleges. The main consideration is about the subject's complexity as it contains many formulas that is very difficult to memorize. To overcome these issues, activity based events related to the math like quizzes, exhibitions showing the models, seminars, refresher courses are recommended to make the subject more interesting to study than by compulsion.

Case 3:

According to research by Stephanus [6], the experiential learning method emphasizes the role of active experience and the involvement of students. Through authentic practice-based learning, students' experiences will lead to the self-efficacy which in turn results in their confidence to handle a specific task.

\section{Case 4:}

According to a study conducted by Morris [7], experiential learning consists of contextually rich concrete experience, critical reflective observation, contextual-specific abstract conceptualization, and pragmatic active experimentation. 


\section{Case 5:}

According to a study conducted by Egilmez [8], in this study, the researchers focused on investigating the learning effectiveness of an online ethics module developed for and implemented in a senior year Engineering Ethics Seminar course. The module consisted of three pillars: code of ethics, case studies, and methods for applying ethical reasoning. Each pillar requires the student to take a quiz consisting of 4 to 7 questions, and a final 10 question quiz at completion of the module. In-class activities and assignments complement the module. The research team conducted a two-semester assessment on learning effectiveness of the online ethics module with a sample of 41 engineering students from well-represented diverse majors, self-identification and racial/ethnic backgrounds compared to the enrollment population. Results indicate that the proposed online module positively impacted the students' proficiency in knowledge of ethics and ethical reasoning in terms of students' perception of improved confidence and the instructor's assessment.

\section{Challenges:}

In the literature carried out in the contribution of other stakeholders to improve the performance of students, the author discusses few major challenges facing by India and steps taken by the government with regard to the problem. Few of the issues listed by the author are: Inadequate infrastructure, less exposure to good research, less number of industry-university tie-ups [9]. Also a recent article by The New Times newspaper [10], an English teacher named Aminadhad Niyoshunti, based on the country Rwanda, suggests that the parental guidance is also required in shaping the behavior of the student.

\section{Solutions:}

In the open-ended style, the problem can be approached with multiple ways to attain the efficient solution and there is no most ideal method to put in practice [11]. Henceforth, the students finds complete independence in approaching and exploring the problem in their own drive and innovation $[12,13]$. Experiential mode of learning enhances the learning capacity, confidence, creativeness of students and make them industry prepared [14]. Also, it provides a high level of spirit to work like a practiced professional [15]. Hence, the literature emphasizes that experiential learning improves the student's confidence, performance and involvement drastically.

\section{Methodology}

\subsection{Research Design}

The course considered for investigation in this paper is data structures as it plays a significant role in Information technology domain placements. The proposed methodology describes the activity based experiential learning carried out in the laboratory and in each and every component of the course. The implementation model, overall impact on students' performance and learning experiences also elaborated in this study. As a part of B.Tech-IT curriculum of PSG College of Technology to strengthen the students' ability in developing and analyzing algorithm efficiently, five courses are included, namely, Data Structures, Design and Analysis of Algorithms, Data Structures Laboratory, Advanced Data Structures and Advanced Data Structures Laboratory. These courses promise in-depth coverage towards Placement preparation/Higher Studies from the second year onwards of student's candidacy.

As a part of these courses, apart from teaching the topics as per syllabus, Tutorial questions are given in the class based on recent GATE Exam question papers and from frequently asked placement questions from various forums. For assignment presentations, coding based challenging questions from HackerRank, CodeChef, GeeksforGeeks, HackerEarth and UPSC are given and the students are advised to come up with multiple independent solutions/methodologies for the same problem by ascertaining the time and space complexity of the program/problem/application. Inherently the students are able to get a clear insight to apply different strategies for the same program/problem/application and analyzing the same. By comparing various methods for the same problem, students are able to approach the same problem in multiple ways to identify the optimal (best) solution as an outcome for this research study. Rubrics also adopted to avoid large variations in the assessment procedure.

During laboratory sessions, placement based questions related to the activity/exercise are given as practice questions for implementation. As an outcome, in-depth knowledge is assured for the respective activity/exercise. To emphasize this innovative pedagogy, few lab tests/Department placement training sessions are conducted in HackerRank as an execution environment to make the 
students familiar with the environment that benefit them during their placements. Students are ranked based on the Cumulative score obtained in the components, namely, Tutorials, Assignment Presentation and Department Placement Training Sessions and appreciated during the IT Association Award Ceremony to motivate the young minds. Students show a lot of interest in developing the optimal solution for contemporary interdisciplinary applications/real world problems with greater independence that leads as a way to Project-based laboratory. Also, while solving the problem as a group, teamwork skills and coordination skills are enhanced among the students and able to manage the competitive and stressful environments.

\subsection{Experiential Learning vs. Traditional Learning}

A detailed comparison and benefits of experiential learning vs. traditional learning is presented in Table 1.

Table 1. Comparison of Experiential Learning with Traditional Learning

\begin{tabular}{lcc}
\hline \multicolumn{1}{c}{ Activities/Skills } & $\begin{array}{c}\text { Experiential } \\
\text { Learning }\end{array}$ & $\begin{array}{c}\text { Traditional } \\
\text { Learning }\end{array}$ \\
\hline $\begin{array}{l}\text { Briefing on theory, tutorial questions, } \\
\text { assignment questions and laboratory } \\
\text { questions }\end{array}$ & $X$ & $\sqrt{ }$ \\
\hline Deriving execution model & $\sqrt{ }$ & $X$ \\
\hline $\begin{array}{l}\text { Designing multiple solutions for a } \\
\text { problem }\end{array}$ & $\sqrt{ }$ & $\sqrt{ }$ (To some extent) \\
\hline Identifying the optimal (best) solution & $\sqrt{ }$ & (To some extent) \\
\hline Assurance of in-depth knowledge & $\sqrt{ }$ & $X$ \\
\hline Creativity \& analyzing skills & $\sqrt{ }$ & $X$ \\
\hline $\begin{array}{l}\text { Exploration \& interpretation skills } \\
\text { Gaining motivation \& self- } \\
\text { confidence }\end{array}$ & $\sqrt{ }$ & $\mathrm{X}$ \\
\hline
\end{tabular}

\section{Finding and Discussion}

\subsection{Data analysis}

42 students were chosen as a case study for a detailed analysis on experiential learning in 2017/2018 and 70 students were chosen for a case study in 2019/2020. High level challenging questions was posted to students during laboratory sessions and as tutorial as a trial. Prior to the contest, students were briefed about the working in the environment. A detailed note on solving challenges/problems in the practiced environment is demonstrated.

Pictorial representation of the contest statistics is shown in Figure 1.

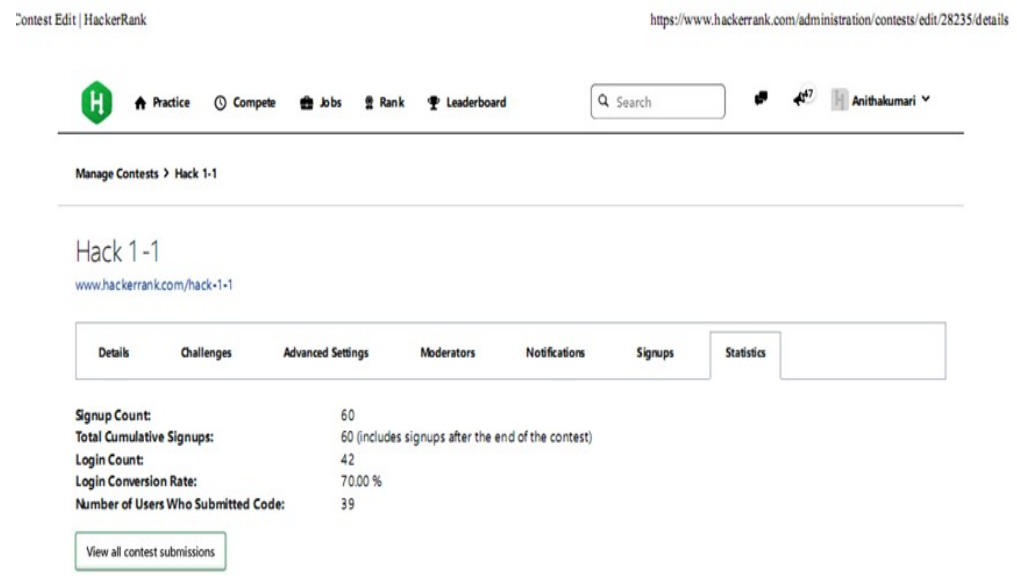

Figure 1. Hacker Rank Contest for Data Structures 
The contest is conducted on the HackerRank platform for highly challenging questions where all possible test cases and restrictions are added and given as input. Students are highly prepared and eagerly participated in the contest for gaining an experiential mode of learning. Lecturers are not required, but initially present to facilitate the students.

From student's side, a complete independence is provided in selecting the programming language for execution. A systematic way of executing the contest was discussed with students with 4 hours onlab session initially and dropped to 3 hours on-lab session later.

Scores obtained after successfully submitting the code are encountered as their component marks for data structure course. The scores obtained by the students are shown in Figure 2.

All Contests > Hack 1-1

\section{Leaderboard}

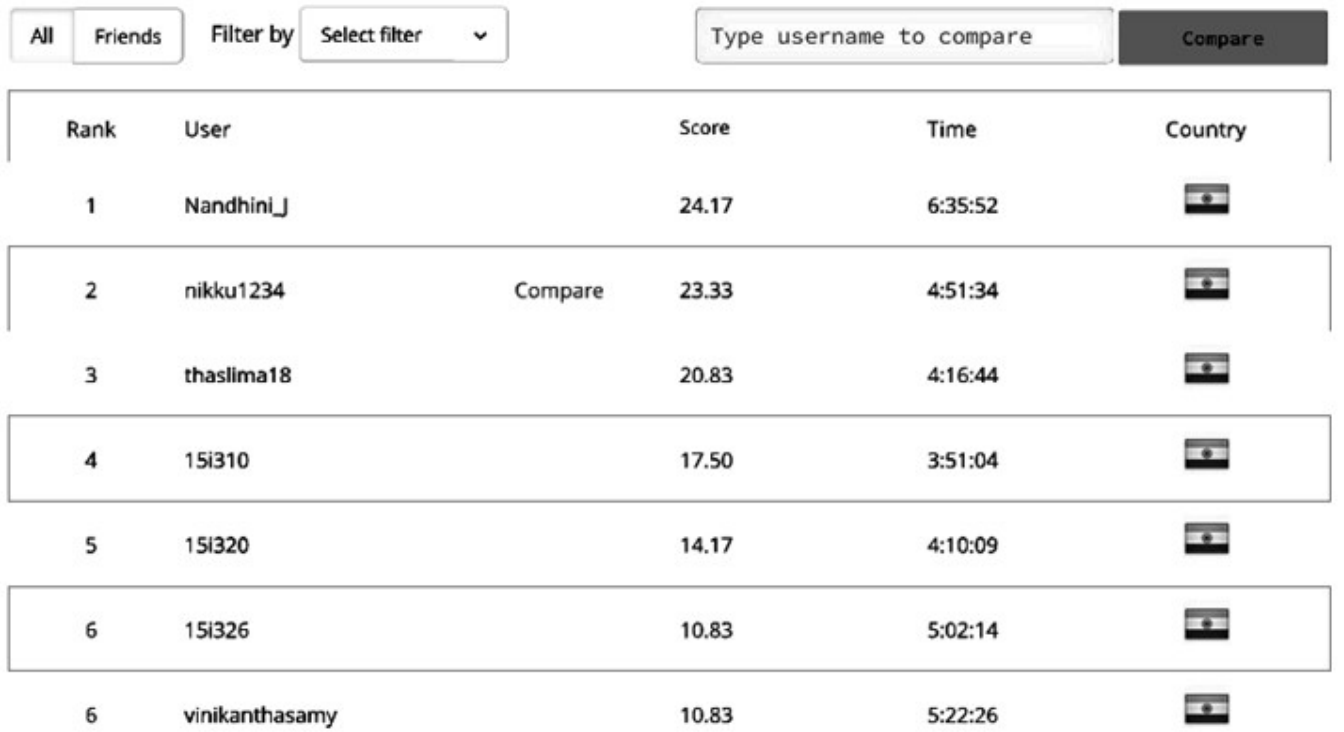

Figure 2. Leaderboard: Scores of Students in 2017/2018

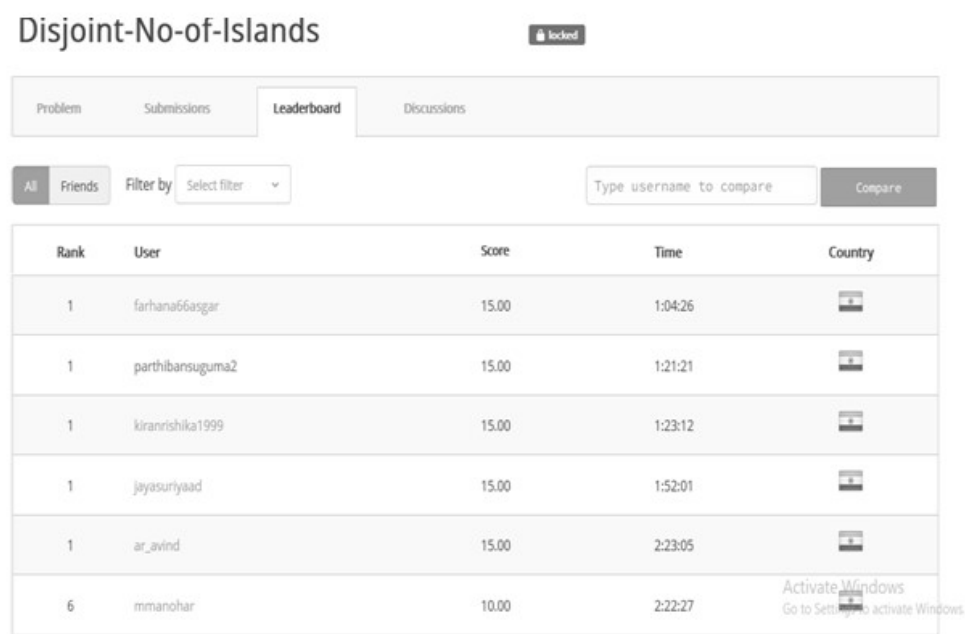

Figure 3. Leaderboard: Scores of Students in 2019/2020 
As the score analysis is a versatile tool to measure the efficiency of the students, it is considered as a metric in our study to measure the strength and weakness of students. Out of 42 students attended the contest, 39 students successfully submitted the code.

From Figure 4, our analysis revealed that, 3 students completed the programs in an exceptional manner by providing an effective solution satisfying all test cases. 30 students are very likely to perform well and the analysis discloses that high/extra attention required for 6 students. It's quite a remarkable result that facilitates to identify the position of students.

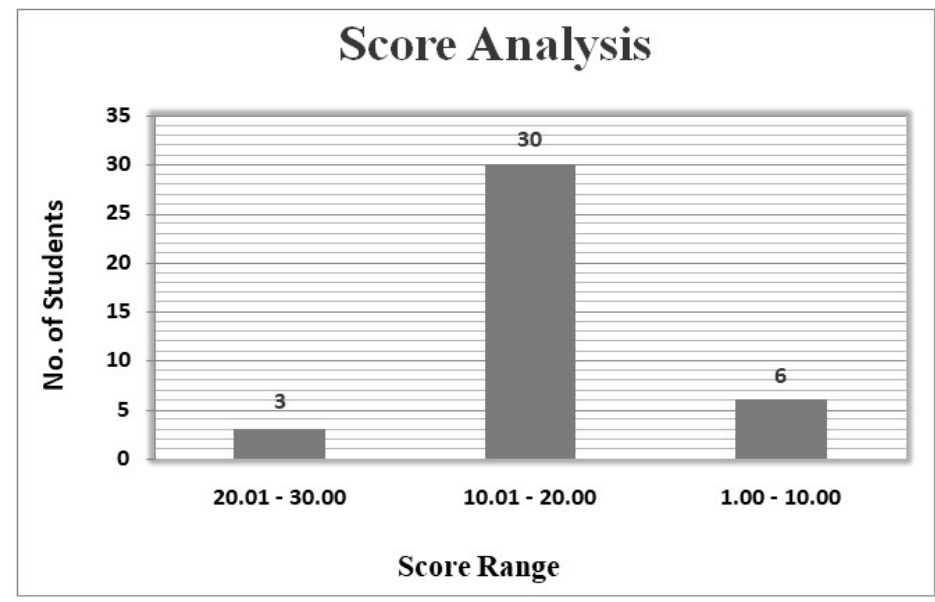

Figure 4. Score Analysis

This acts as an evidence that students' participation in experiential learning facilitates to improve their performance in a better manner by knowing where they are standing in than the traditional way of learning. In summary, our findings emphasize that experiential learning enhances students analyzing skills and paves way for improvement in the academics.

\subsection{T-Test}

It is used for comparing two groups based on their mean scores-test is based on t-distribution and is considered an appropriate test for judging the significance of a sample mean or for judging the significance of difference between the means of two samples in case of small samples when population variance is not known.

In case of two samples are related paired t- test for judging the significance of the mean of difference between the two related samples.

\subsection{Null Hypothesis}

There is no significant difference between experimental learning and traditional learning in the various rating given by the respondents.

\subsection{Group Statistics}

Group statistics are presented in Table 2 and Table 3.

\subsection{Interpretation}

Since SIG value is less than 0.05 , for Deriving execution model, designing multiple solutions for a problem, identifying the optimal (best) solution, Assurance of in-depth knowledge Creativity \& analyzing skills Exploration \& interpretation skills, Gaining motivation \& self-confidence null hypothesis is rejected. Therefore there is rating difference in all the parameters among Experiential Learning and Traditional Learning, From the $\mathrm{T}$ test we can conclude that Experiential Learning is better and optimal when compared to Traditional Learning. 
Table 2. Group Statistics-1

\begin{tabular}{|c|c|c|c|c|c|}
\hline Parameters & Activity/Skills & $\mathbf{N}$ & Mean & Std.Deviation & Std.Error Mean \\
\hline \multirow{2}{*}{$\begin{array}{l}\text { Briefing on } \\
\text { theory, tutorial } \\
\text { questions, } \\
\text { assignment } \\
\text { questions and } \\
\text { laboratory } \\
\text { questions }\end{array}$} & $\begin{array}{l}\text { Experiential } \\
\text { Learning }\end{array}$ & 30 & 3.2747 & 0.39514 & 0.04717 \\
\hline & $\begin{array}{l}\text { Traditional } \\
\text { Learning }\end{array}$ & 12 & 3.2080 & 0.46415 & 0.10283 \\
\hline \multirow{2}{*}{$\begin{array}{l}\text { Deriving } \\
\text { execution model }\end{array}$} & $\begin{array}{l}\text { Experiential } \\
\text { Learning }\end{array}$ & 30 & 3.1713 & 0.46455 & 0.05507 \\
\hline & $\begin{array}{l}\text { Traditional } \\
\text { Learning }\end{array}$ & 12 & 2.1760 & 0.26287 & 0.07377 \\
\hline \multirow{2}{*}{$\begin{array}{l}\text { Designing } \\
\text { multiple solutions } \\
\text { for a problem }\end{array}$} & $\begin{array}{l}\text { Experiential } \\
\text { Learning }\end{array}$ & 30 & 3.1973 & 0.39318 & 0.05757 \\
\hline & $\begin{array}{l}\text { Traditional } \\
\text { Learning }\end{array}$ & 12 & 3.1200 & 0.44377 & 0.12075 \\
\hline \multirow{2}{*}{$\begin{array}{l}\text { Identifying the } \\
\text { optimal (best) } \\
\text { solution }\end{array}$} & $\begin{array}{l}\text { Experiential } \\
\text { Learning }\end{array}$ & 30 & 2.7600 & 0.28899 & 0.03347 \\
\hline & $\begin{array}{l}\text { Traditional } \\
\text { Learning }\end{array}$ & 12 & 2.7800 & 0.38078 & 0.07816 \\
\hline \multirow{2}{*}{$\begin{array}{l}\text { Assurance of in- } \\
\text { depth knowledge }\end{array}$} & $\begin{array}{l}\text { Experiential } \\
\text { Learning }\end{array}$ & 30 & 3.1810 & 0.98740 & 0.11450 \\
\hline & $\begin{array}{l}\text { Traditional } \\
\text { Learning }\end{array}$ & 12 & 3.1080 & 0.88462 & 0.09723 \\
\hline \multirow{2}{*}{$\begin{array}{l}\text { Creativity \& } \\
\text { analyzing skills }\end{array}$} & $\begin{array}{l}\text { Experiential } \\
\text { Learning }\end{array}$ & 30 & 3.1877 & 0.99472 & 0.22453 \\
\hline & $\begin{array}{l}\text { Traditional } \\
\text { Learning }\end{array}$ & 12 & 3.1869 & 0.36127 & 0.011452 \\
\hline \multirow{2}{*}{$\begin{array}{l}\text { Exploration \& } \\
\text { interpretation } \\
\text { skills }\end{array}$} & $\begin{array}{l}\text { Experiential } \\
\text { Learning }\end{array}$ & 30 & 3.4678 & 0.999172 & 0.06789 \\
\hline & $\begin{array}{l}\text { Traditional } \\
\text { Learning }\end{array}$ & 12 & 3.4589 & 0.33042 & 0.06950 \\
\hline \multirow{2}{*}{$\begin{array}{l}\text { Gaining } \\
\text { motivation \& self- } \\
\text { confidence }\end{array}$} & $\begin{array}{l}\text { Experiential } \\
\text { Learning }\end{array}$ & 30 & 3.4567 & 0.33452 & 0.06648 \\
\hline & $\begin{array}{l}\text { Traditional } \\
\text { Learning }\end{array}$ & 12 & 3.1456 & 0.23145 & 0.14752 \\
\hline
\end{tabular}


Table 3. Group Statistics-2

\begin{tabular}{|c|c|c|c|c|c|c|}
\hline \multirow{2}{*}{ PARAMETERS } & \multirow{2}{*}{ VARIANCES } & \multicolumn{2}{|c|}{$\begin{array}{c}\text { Levene's Test } \\
\text { for equality of } \\
\text { Variances } \\
\end{array}$} & \multicolumn{3}{|c|}{$\begin{array}{c}\text { T-test for Equality of } \\
\text { Means }\end{array}$} \\
\hline & & $\mathbf{F}$ & Sig. & $\mathbf{t}$ & df & $\begin{array}{l}\text { Sig. } \\
\text { (2 } \text {-tailed) }\end{array}$ \\
\hline \multirow{2}{*}{$\begin{array}{l}\text { Briefing on theory, } \\
\text { tutorial questions, } \\
\text { assignment questions } \\
\text { and laboratory } \\
\text { questions }\end{array}$} & $\begin{array}{l}\text { Equal variance } \\
\text { assumed }\end{array}$ & 1.090 & 0.258 & 0.553 & 40 & 0.457 \\
\hline & $\begin{array}{l}\text { Equal variance } \\
\text { assumed }\end{array}$ & 4.397 & 0.033 & 1.504 & 40 & 0.090 \\
\hline \multirow{2}{*}{$\begin{array}{l}\text { Deriving execution } \\
\text { model }\end{array}$} & $\begin{array}{l}\text { Equal variance } \\
\text { assumed }\end{array}$ & 0.016 & 0.634 & 1.520 & 40 & 0.031 \\
\hline & $\begin{array}{l}\text { Equal variance } \\
\text { assumed }\end{array}$ & 0.403 & 0.380 & 1.403 & 40 & 0.123 \\
\hline \multirow{2}{*}{$\begin{array}{l}\text { Designing multiple } \\
\text { solutions for a problem }\end{array}$} & $\begin{array}{l}\text { Equal variance } \\
\text { assumed }\end{array}$ & 0.678 & 0.480 & 0.531 & 40 & 0.021 \\
\hline & $\begin{array}{l}\text { Equal variance } \\
\text { assumed }\end{array}$ & 0.146 & 0.146 & 0.124 & 40 & 0.124 \\
\hline \multirow{2}{*}{$\begin{array}{l}\text { Identifying the optimal } \\
\text { (best) solution }\end{array}$} & $\begin{array}{l}\text { Equal variance } \\
\text { assumed }\end{array}$ & 1.146 & 0.186 & 0.146 & 40 & 0.003 \\
\hline & $\begin{array}{l}\text { Equal variance } \\
\text { assumed }\end{array}$ & 0.416 & 0.345 & 0.452 & 40 & 0.090 \\
\hline \multirow{2}{*}{$\begin{array}{l}\text { Assurance of in-depth } \\
\text { knowledge }\end{array}$} & $\begin{array}{l}\text { Equal variance } \\
\text { assumed }\end{array}$ & 1.176 & 0.478 & 1.145 & 40 & 0.040 \\
\hline & $\begin{array}{l}\text { Equal variance } \\
\text { assumed }\end{array}$ & 0.145 & 0.123 & 1.789 & 40 & 0.668 \\
\hline \multirow{2}{*}{$\begin{array}{c}\text { Creativity \& analyzing } \\
\text { skills }\end{array}$} & $\begin{array}{l}\text { Equal variance } \\
\text { assumed }\end{array}$ & 4.456 & 0.356 & 2.172 & 40 & 0.001 \\
\hline & $\begin{array}{l}\text { Equal variance } \\
\text { assumed }\end{array}$ & 2.256 & 0.145 & 2.145 & 40 & 0.949 \\
\hline \multirow{2}{*}{$\begin{array}{c}\text { Exploration \& } \\
\text { interpretation skills }\end{array}$} & $\begin{array}{l}\text { Equal variance } \\
\text { assumed }\end{array}$ & 2.146 & 0.785 & 1.124 & 40 & 0.042 \\
\hline & $\begin{array}{l}\text { Equal variance } \\
\text { assumed }\end{array}$ & 1.236 & 0.169 & 0.121 & 40 & 0.543 \\
\hline \multirow{2}{*}{$\begin{array}{l}\text { Gaining motivation \& } \\
\text { self-confidence }\end{array}$} & $\begin{array}{l}\text { Equal variance } \\
\text { assumed }\end{array}$ & 3.456 & 0.998 & 0.025 & 40 & 0.003 \\
\hline & $\begin{array}{c}\text { Equal variance } \\
\text { assumed }\end{array}$ & 2.412 & 0.124 & 0.456 & 39 & 0.372 \\
\hline
\end{tabular}




\section{Conclusion}

As an inference, this restructured mode of learning for the courses Data Structures, Design and Analysis of Algorithms, Data Structures Laboratory, Advanced Data Structures and Advanced Data Structures Laboratory results in stimulating the students' creativity, analyzing skills, exploration skills, interpretation skills and thereby gaining motivation and self-confidence. With high level of confidence, designing efficient (best) solution during interviews becomes reality and thereby results in the continued growth of the department and institution this also is confirmed by the statistical Ttest.

\section{References}

[1] C. Hart, P. Mulhall, A. Berry, J. Loughran, and R. Gunstone, "What is the purpose of this experiment? Or can students learn something from doing experiments," Journal of Research in Science Teaching, vol. 37, no. 7, pp. 655-675, 2000.

[2] -, "Experiential Education: New Opportunities for Transforming the Student Experience". April 2014.

[3] A. G. Cavinato, "Challenges and successes in implementing active learning laboratory experiments for an undergraduate analytical chemistry course," Analytical and Bioanalytical Chemistry, vol 409, no. 6, pp. 1465-1470, 2017.

[4] J. A Pereira, A. Merí, C. Masdeu, M. C. Molina-Tomás, and A. Martínez-Carrió, "Using videoclips to improve theoretical anatomy teaching," European Journal of Anatomy, vol. 8, no. 3, pp. 143-146, 2004.

[5] K. G. Singha, M.Goswami, and Ranju Kr. Bharali, "Study of Various Problems Faced By the Students and Teachers in Learning \& Teaching Mathematics and Their Suggestive Measures," International Journal of Advanced Research in Management and Social Science, vol. 1, no. 2, pp. 195-201, 2012.

[6] Stephanus, "Kolb's Experiential Learning for Vocational Education in Mechanical Engineering: A Review," September 2, 2001. [Online]. Available: https://aip.scitation.org/doi/abs/10.1063/1.5112427. [Accessed: 2020].

[7] T. H. Morris, "Assessing an Online Engineering Ethics Module from Experiential Learning Perspective," 2018. [Online]. Available: https://digitalcommons.newhaven.edu/sgiengineeringfacpubs/30/. [Accessed: 2020].

[8] G. Egilmez, "Assessing an Online Engineering Ethics Module from Experiential Learning Perspective," 2019. [Online]. Available: https://digitalcommons.newhaven.edu/sgiengineeringfacpubs/32/. [Accessed: 2020].

[9] S. Sharma, and P. Sharma, "Indian Higher Education System: Challenges and Suggestions," Electronic Journal for Inclusive Education, vol. 3, no. 4, pp. 1-6, 2015.

[10] -, "Strategies to Improve Academic Outcome," 2019. [Online]. Available: https://www.newtimes.co.rw/lifestyle/strategies-improve-academic-outcomes. [Accessed: 2020].

[11] M. L. Susan, "Cognitive Requirements or Learning with Open-ended learning Environments," ETR \& D, vol. 48, no. 3, pp. 61-78, 2000.

[12] D. R. Mills, "Scientific abilities in undergraduate projects and laboratory," New Directions in the Teaching of Physical Sciences, vol. 3, pp. 69-72, 2018.

[13] S. Mohammad, M. Mustaffar, Z. Haron, A. R. Sam, and J. M. Yatim, "The Implementation of an Open-ended Experiment in the Civil Engineering Laboratory," Procedia - Social and Behavioral Sciences, vol. 102 (Ifee 2012), pp. 548-559, 2013.

[14] C. Gormally, P. Brickman, Hallar, and N. Armstrong, "Effects of Inquiry-based Learning on Students' Science Literacy Skills and Confidence," International Journal for the Scholarship of Teaching and Learning, vol. 3, no. 2, 2016.

[15] J. C. Wright, "Authentic Learning Environment in Analytical Chemistry Using Cooperative Methods and Open-Ended Laboratories in Large Lecture Courses," Journal of Chemical Education, vol. 73, no. 9, pp. 827, 2009. 


\section{Biography}

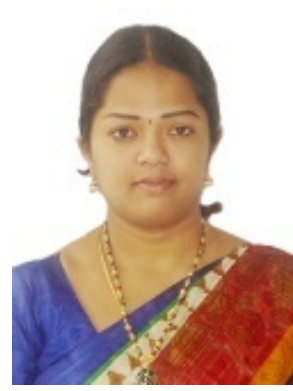

Dr. K. Anitha Kumari is working as an Associate Professor in Department of IT in PSG College of Technology, India. She is Highly Passionate and curious about Learning New stuffs in Security Protocols. As an Independent Researcher, she had an Opportunity to present her paper based on Quantum Cryptography in USA and visited a few Foreign Universities. To her credit, she had filed a PATENT and published around 50 Technical Papers in refereed and Impact Factored International/National Journals/Conferences published by Elsevier, Springer,T\&F,Etc.,.Also, she's been an Active Reviewer for Prestigious Journals published by Springer,Wiley,etc.,and Technical Program Committee (TPC) for CECNet 2017, NGCT-2017 WICC-2018 and NCCI-2018 conferences. Her areas of interest include Cloud \& IoT Security, Design and Analysis of Security Protocols, Attacks \& Defense, Security in Computing, Bioinformatics, Cognitive Security, Quantum Cryptography, Web Service Security, Network Security and Analysis of Algorithms. Out of her research interest, she has contributed a Book chapter in T \& F and delivered ample Guest Lectures. Her security project is Recommended by AICTE for a sum of Rs.20,00,000/-. She's been the mentor for Technovator Projects (2018 \& 2014) and 'MEDROIDZ', an ICICI - Trinity 2014 funded project that was selected as one among the 6 projects in India. Academically, she has secured RANK-I and awarded Gold Medal in ME (SE) \& in BE (CSE) from Anna University and from Avinashilingam University. She won prizes in intra and inter institutional cultural events. As a Supervisor, she is currently guiding PhD scholars. You may contact her at anitha.psgsoft@gmail.com/kak.it@psgtech.ac.in.

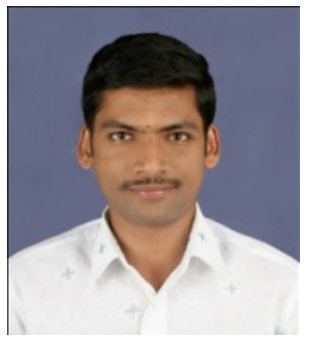

Dr. L. Nanda Gopal is working as an Assistant Professor in the Department of Humanities PSG College of Technology he obtained his master degree in Management, Commerce and International business. His MPhil Dissertation Study on Consumer Satisfaction of Maruti Suzuki Cars in Coimbatore City was Highly commended by the examiners of Bharathiar University. His Doctoral research was successfully completed in the area of Brand Awareness and Fast-food Purchase Behaviour- An exploratory study in the year 2016. He has published several research articles in the reputed journals, an article in scopus indexed journal titled The consumer behaviour towards online shopping in coimbatore city - An exploratory study, and presented several papers at national and international conferences. He has successfully completed the FDP101x foundation program in ICT for Education from 3/8/17 to 7/9/17 and FDP201x Pedagogy for Online and Blended Teaching- Learning Process from 14/9/17 to 12/10/17, the FDP Conducted by Indian Institute of Technology Bombay was held under the aegis of Pandit Madan Mohan Malaviya National Mission for Teachers and Teaching- Ministry of Human Resource Development- Government of India. He successfully completed several MOOC Online courses such that Elements of learner centric mooc, 3D Animation, 3D Visualization and Effective teaching strategies from IIT Bombay. He is certified by the british council for attending a personality development course in the year 2015 by Hindustan Unilever Ltd. Apart from teaching he has worked as a trainer and marketer for HDFC BANK, Fullerton India Credit Company Ltd and worked as an Assistant Manager in Shriram Group of Companies. You may contact him at nandagopa183@gmail.com / lng.hum@psgteh.ac.in.

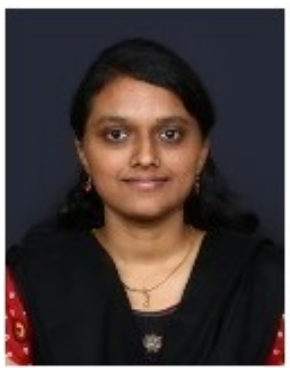

Ms. R. Padmashaniis working as an Assistant Professor[Sr.Gr] in the Department of Information Technology, PSG College of Technology, Coimbatore. She obtained her Master's Degree in Computer Science and Engineering and currently pursuing her Doctoral research in the area of Network Security. Her areas of interest include Machine Learning, Network Security, Deep Learning, Data structures, Algorithm analysis, and Cryptography. She has published papers in several National and International Journals and in Conferences. Her honor, she received the Best Paper Award as a part of her research work. She is a meritorious student in her UG programme. You may contact her at padmashani@gmail.com. 